\title{
Roles of Midwives and Indonesian Midwives Association in Reducing Risk Factors for Stunting in Indonesia
}

\author{
Sumiaty Sumiaty ${ }^{1 *(\mathbb{D})}$, Muhammad Nur $\mathrm{Ali}^{2}$ iD, Hasan Muhammad² ${ }^{2}$, Fahmi $\operatorname{Hafid}^{3}$ (D) \\ ${ }^{1}$ Department of Midwifery, Poltekkes Kemenkes Palu, Palu, Indonesia; ${ }^{2}$ Faculty of Social and Political Science, Tadulako \\ University, Palu, Indonesia; ${ }^{3}$ Department of Nutrition, Poltekkes Kemenkes Palu, Palu, Indonesia
}

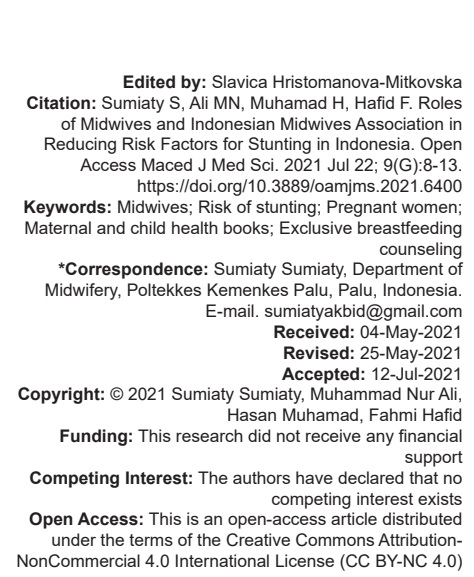

\section{Introduction}

Stunting is caused by multi-dimensional factors and the most decisive intervention should be carried out in the first 1000 days of life. Poor parenting practices, lack of knowledge about health and nutrition before and during pregnancy are among the contributing factors. In addition, sixty percent of children aged 0-6 months do not receive exclusive breastfeeding, two out of three children aged $0-24$ months do not receive complementary foods, and the availability of health services including antenatal care and postnatal care are limited. Two out of three pregnant women have not taken adequate iron supplements and lack of access to nutritious food. One of three pregnant women with anemia is a factor causing stunting in Indonesia [1].

The Basic Health Research by the Ministry of Health of the Republic of Indonesia reported that the national prevalence of child stunting in 2013 was $37.2 \%$ and decreased in 2018 to $30.2 \%$ [2], [3].
Despite the decline, the problem of stunting still needs to be controlled [4]. Maternal and child health services carried out by midwives play an important role in the prevalence of stunting. The results showed that maternal height $<150 \mathrm{~cm}$, birth spacing $<3$ years and the absence of antenatal care were risk factors for stunting [5]. Research in Ethiopia shows risk factors for stunting include maternal age $>30$ years, mothers without formal education, mothers who work every day, mothers who do not perform postnatal care, and mothers who are sick during their pregnancy [6]. Research in Bhutan shows the risk factors for stunting in children 6-23 months are; antenatal care factor is less than $\leq 3$ times, do not perform antenatal care on doctors, nurses and midwives, and mothers who are $<18$ years old [7].

In line with that, prevention efforts can be carried out by streamlining existing health programs such as antenatal care, classes for pregnant women, iron and calcium supplementation, and supplementary feeding for pregnant women [8]. Specifically, a study also recommended long breastfeeding through 
breastfeeding behavior enhancement programs [9]. In 2018, the Government allocated national priority projects to reduce stunting, one of which is to improve maternal and reproductive health services [1]. Stunting prevention activities are also determined by the role of midwives engaged in antenatal care, postnatal care, iron tablets, calcium for pregnant women, classes for pregnant women, and the provision of additional food for pregnant women.

The purpose of the current study is to assess the role of Midwives and the Indonesian Midwives Association Professional Organization in reducing the risk of stunting in Indonesia.

\section{Methods}

This type of descriptive research uses an exploratory study approach. Data of 288 midwives were collected using google form from 22 July 2020 to 22 August 2020 with URL: https://forms.gle/ MMd5ijjESSZkBvj16.

The research sample was midwives from all over Indonesia and who successfully filled out the questionnaire a total of 288 people. The inclusion criteria for this study were a midwives, active as a member of the Indonesian Midwives Association Professional Organization, worked for 2 years, had Registration Certificate of midwives, had attended a socialization about preventing stunting. The exclusion criteria were working for $<2$ years, not having Registration Certificate of midwives, and not working in a health facility.

The instrument for data collection used was a research questionnaire using Google Form which was distributed through the WhatsApp group of Indonesian midwives. The variables include; the role of the Indonesian Midwives Association and the prevalence of children under two in Indonesia; socializing the program for the first 1000 days of life; participating in scientific activities related to stunting; providing/assisting antenatal care training related to stunting. Roles of midwives and prevalence of stunting among children under two in Indonesia include: Provide maternal and child health books to pregnant women; complete maternal and child health books; carry out antenatal care for pregnant women; provide nutritional advice to pregnant women; Give Fe tablets 90 seeds to pregnant women; provide calcium tablets to pregnant women, preparation of classes for pregnant women, implementation of a special prevention program, implementation of postnatal care, delay in umbilical cord-cutting (>30 min), early initiation of breast-feeding, provision of Vitamin A to postpartum mothers, exclusive breastfeeding counseling, provision of family planning services, and provision of complementary breastfeeding counseling.
Data analysis is descriptive analysis on respondent characteristics and bivariate analysis to test the Role of Indonesian Midwives Association and prevalence of stunting in Children Under Two in Indonesia using the Chi-Square Test with a significant level of $p<0.05$.

\section{Results}

In general, respondents aged 20-35 years (86.5\%). They work as a midwife for $<5$ years $(58.7 \%)$, have a 3 -year midwifery diploma $(75.3 \%)$, work in a hospital $(40.3 \%)$, and not as an administrator of the Indonesian midwifery association (61.8\%) (Table 1).

Table 1: Respondents characteristics

\begin{tabular}{lll}
\hline Variable & $n(288)$ & $\%$ \\
\hline Age & 249 & 86.5 \\
$20-35$ years & 37 & 12.8 \\
$36-50$ years & 2 & 0.7 \\
$>50$ years & & \\
Length of work As Midwifery & 169 & 58.7 \\
$\quad$ 5 years & 63 & 21.9 \\
$5-10$ years & 56 & 19.4 \\
$>10$ years & & \\
Education & 217 & 75.3 \\
$\quad$ Diploma III & 64 & 22.2 \\
Diploma IV/Graduate & 7 & 2.4 \\
$\quad$ Post Graduate & 11 & 3.8 \\
Work place & 17 & 5.9 \\
$\quad$ Public Health Office & 33 & 11.5 \\
$\quad$ Educational Institution & 111 & 38.5 \\
$\quad$ Non-governmental organization & 116 & 40.3 \\
Public health center & & \\
Hospital \\
Management of the Indonesian Midwives Association & 110 & 38.2 \\
Yes & 178 & 61.8 \\
$\quad$ No & & \\
\hline
\end{tabular}

Table 2 shows that there is no significant relationship in the variable socializing the program for the first 1000 days of life, participate in scientific activities related to stunting, Provide/Attend Antenatal care training related to stunting against the prevalence of stunting in children under two with a $p>0.05$. Then, table 3 shows that implement postnatal care as a duty of

Table 2: Role of Indonesian midwives association and prevalence of stunting in children under two in Indonesia

\begin{tabular}{|c|c|c|c|c|c|}
\hline \multirow[t]{3}{*}{ Variable } & \multicolumn{4}{|c|}{$\begin{array}{l}\text { Prevalence of Stunting in } \\
\text { Children Under Two }\end{array}$} & \multirow[t]{3}{*}{$p$-value } \\
\hline & \multicolumn{2}{|c|}{$30-40 \%$} & \multicolumn{2}{|c|}{$<29.9 \%$} & \\
\hline & $n$ & $(\%)$ & $n$ & $(\%)$ & \\
\hline \multicolumn{6}{|c|}{ Socializing the Program for the first 1000 days of life } \\
\hline Never & 43 & 46.2 & 50 & 53.8 & \\
\hline Once a year & 15 & 62.5 & 9 & 37.5 & 0.215 \\
\hline Once per semester & 19 & 65.5 & 10 & 34.5 & \\
\hline Once a month & 77 & 54.2 & 65 & 45.8 & \\
\hline \multicolumn{6}{|c|}{ Participate in scientific activities related to stunting } \\
\hline Never & 53 & 50.0 & 53 & 50.0 & \\
\hline Once a year & 21 & 65.6 & 11 & 34.4 & 0.346 \\
\hline Once per semester & 20 & 60.6 & 13 & 39.4 & \\
\hline Once a month & 60 & 51.3 & 57 & 48.7 & \\
\hline $\begin{array}{l}\text { Provide/Attend Antena } \\
\text { stunting }\end{array}$ & 64 & 53.3 & 56 & 46.7 & \\
\hline Never & 18 & 69.2 & 8 & 30.8 & 0.158 \\
\hline Once a year & 16 & 64.0 & 9 & 36.0 & \\
\hline $\begin{array}{l}\text { Once per semester } \\
\text { Once a month }\end{array}$ & 56 & 47.9 & 61 & 52.1 & \\
\hline
\end{tabular}


Table 3: Role of midwives and prevalence of stunting children under two in Indonesia

\begin{tabular}{|c|c|c|c|c|c|}
\hline \multirow[t]{3}{*}{ Variable } & \multicolumn{4}{|c|}{$\begin{array}{l}\text { Prevalence of stunting children } \\
\text { under Two }\end{array}$} & \multirow[t]{3}{*}{$\mathrm{p}$-value } \\
\hline & \multicolumn{2}{|c|}{$30-40 \%$} & \multicolumn{2}{|c|}{$<29.9 \%$} & \\
\hline & $\mathrm{n}$ & $(\%)$ & $\mathrm{n}$ & $(\%)$ & \\
\hline \multicolumn{6}{|c|}{$\begin{array}{l}\text { Provide maternal and child health books to } \\
\text { pregnant women }\end{array}$} \\
\hline Never & 14 & 60.9 & 9 & 39.1 & 0.349 \\
\hline Rarely & 18 & 43.9 & 23 & 56.1 & \\
\hline Frequency & 122 & 54.5 & 102 & 45.5 & \\
\hline \multicolumn{6}{|c|}{ Complete maternal and child health books } \\
\hline Never & 5 & 31.3 & 11 & 68.8 & 0.076 \\
\hline Rarely & 16 & 44.4 & 20 & 55.6 & \\
\hline Frequency & 133 & 56.4 & 103 & 43.6 & \\
\hline \multicolumn{6}{|c|}{ Carrying out Antenatal Care for Pregnant } \\
\hline \multicolumn{6}{|c|}{ Women } \\
\hline Never & 4 & 40.0 & 6 & 60.0 & 0.663 \\
\hline Rarely & 15 & 51.7 & 14 & 48.3 & \\
\hline Frequency & 135 & 54.2 & 114 & 45.8 & \\
\hline \multicolumn{6}{|c|}{$\begin{array}{l}\text { Provide nutritional food counseling for } \\
\text { pregnant women }\end{array}$} \\
\hline Never & 3 & 42.9 & 4 & 57.1 & 0.849 \\
\hline Rarely & 16 & 53.3 & 14 & 46.7 & \\
\hline Frequency & 135 & 53.8 & 116 & 46.2 & \\
\hline \multicolumn{6}{|c|}{ Give Fe tablets 90 seeds to pregnant women } \\
\hline Never & 6 & 42.9 & 8 & 57.1 & 0.409 \\
\hline Rarely & 17 & 45.9 & 20 & 54.1 & \\
\hline Frequency & 131 & 55.3 & 106 & 44.7 & \\
\hline \multicolumn{6}{|c|}{ Give calcium tablets to pregnant women } \\
\hline Never & 5 & 41.7 & 7 & 58.3 & 0.478 \\
\hline Rarely & 18 & 47.4 & 20 & 52.6 & \\
\hline Frequency & 131 & 55.0 & 107 & 45.0 & \\
\hline \multicolumn{6}{|c|}{ Carrying out classes for pregnant women } \\
\hline Never & 6 & 46.2 & 7 & 53.8 & 0.759 \\
\hline Rarely & 19 & 50.0 & 19 & 50.0 & \\
\hline Frequency & 129 & 54.4 & 108 & 45.6 & \\
\hline \multicolumn{6}{|c|}{$\begin{array}{l}\text { Implement a special stunting prevention } \\
\text { program }\end{array}$} \\
\hline Never & 23 & 65.7 & 12 & 34.4 & 0.252 \\
\hline Rarely & 24 & 48.0 & 26 & 52.0 & \\
\hline Frequency & 107 & 52.7 & 96 & 47.3 & \\
\hline Implement Pos & & & & & \\
\hline Never & 21 & 63.6 & 12 & 36.4 & $0.037^{*}$ \\
\hline Rarely & 29 & 40.8 & 42 & 59.2 & \\
\hline Frequency & 104 & 56.5 & 80 & 43.5 & \\
\hline Delay cutting $\mathrm{t}$ & & & & & \\
\hline Never & 6 & 60.0 & 4 & 40.0 & 0.903 \\
\hline Rarely & 25 & 54.3 & 21 & 45.7 & \\
\hline Frequency & 123 & 53.0 & 109 & 47.0 & \\
\hline Perform early i & & & & & \\
\hline Never & 50 & 64.9 & 27 & 35.1 & 0.060 \\
\hline Rarely & 29 & 50.9 & 28 & 49.1 & \\
\hline Frequency & 75 & 48.7 & 79 & 51.3 & \\
\hline Provide Vitami & & & & & \\
\hline Never & 5 & 55.6 & 4 & 44.4 & 0.739 \\
\hline Rarely & 18 & 60.0 & 12 & 40.0 & \\
\hline Frequency & 131 & 52.6 & 118 & 47.4 & \\
\hline Conduct exclu & & & & & \\
\hline Never & 6 & 54.5 & 5 & 45.5 & 0.771 \\
\hline Rarely & 19 & 59.4 & 13 & 40.6 & \\
\hline Frequency & 129 & 52.7 & 116 & 47.3 & \\
\hline Providing famil & & & & & \\
\hline Never & 3 & 50.0 & 3 & 50.0 & 0.388 \\
\hline Rarely & 19 & 65.5 & 10 & 34.5 & \\
\hline Frequency & 132 & 52.2 & 121 & 47.8 & \\
\hline $\begin{array}{l}\text { Providing com } \\
\text { counselling }\end{array}$ & & & & & \\
\hline Never & 3 & 42.9 & 4 & 57.1 & 0.768 \\
\hline Rarely & 16 & 50.0 & 16 & 50.0 & \\
\hline Frequency & 135 & 54.2 & 114 & 45.8 & \\
\hline
\end{tabular}

midwives has a significant relationship to the prevalence of stunting children under two with a value of $p<0.05$.

\section{Discussion}

A midwife is a woman who graduated from a midwifery education recognized by the government and professional organizations in the territory of the Republic of Indonesia and has the competence and qualifications to be registered, certified and/or legally licensed to carry out midwifery practices. Midwives are responsible and accountable professionals, who work as partners for women to provide support, care and advice during pregnancy, labor, and childbirth, facilitate and lead delivery on their own responsibility and provide care for newborns, and babies. This care includes prevention, promotion of normal delivery, detection of complications in mothers and children, and access to medical assistance or other appropriate assistance, as well as carrying out emergency measures [10].

Midwives have an important task in counseling and health education, not only for women but also for families and communities. These activities include antenatal education and preparation for parenthood and can extend to women's health, sexual health or reproductive health, and child care. Midwives can practice in a variety of service settings: including at home, community, hospital, clinic, or other health units [10].

The Indonesian Midwives Association is a professional organization for midwives in Indonesia. It is a midwives' body in achieving their goals through policies to increase the professionalism of members to ensure that the community gets quality services. The Indonesian Midwives Association was founded on 24 June 1951, became a member of the Indonesian Women's Congress in 1951, and joined as a member of the International Confederation of Midwives in 1956. The mission of the Indonesian Midwives Association is to increase organizational strength, increase the role of the Indonesian Midwives Association in improving the quality of midwife education and services, improve the welfare of members and establish cooperation with networks. The values that underlie the Indonesian Midwives Association are prioritizing togetherness, unifying themselves in one forum, protecting members, self-development, participation in the community, maintaining the image of a midwife, and providing quality services to mothers and children.

A retrospective study assessed antenatal use using an index of prenatal care use. The use of intensive antenatal care was noted in more than half of low-risk women. On the other hand, there are 26\% of women at high risk without the expected intensive use. High-risk or non-educated women tend to have higher rates of utilization of antenatal care compared to educated ones [11].

Antenatal care is defined as care provided by skilled health care professionals to pregnant women and women to ensure the best possible health conditions for both mother and baby during pregnancy. ANC components include risk identification; prevention and management of pregnancy-related or concurrent diseases; and health education and health promotion [12]. 
The Svefors (2019) study shows that currently, most interventions are carried out in late infancy and early childhood. Studies that identify the most critical prenatal and postnatal determinants of $0-24$ months linear growth and risk factors for stunting at 2 years show that determinants of stunting in rural young children include a wide range of high-quality prenatal and postnatal data, household and family information, environmental factors, Child characteristic at birth, infant feeding and morbidity. Prenatal factors including childbirth, maternal anthropometry, and parental education are critical factors for stunting at 24 months of age [13].

The study of Schmidt (2002) shows that one of the determinants of growth and nutritional status of infants in Indonesia is a postnatal factor. Neonatal weight $(3.2 \pm 0.5 \mathrm{~kg})$ and length $(49.7 \pm 2.2 \mathrm{~cm})$ are still reasonable. However, growth starts to weaken at the age of $6-7$ months or after delivery resulting in a prevalence of $24 \%$ stunting and $32 \%$ underweight at 12 months of age. Multiple regression models explain $19-41 \%$ of the variation in growth and nutritional status of infants. Neonatal weight $(\beta=0.285)$ and length ( $\beta=0.492)$ were the strongest positive predictors of weight $Z$ score for age and height for age [14].

Study Krisnana (2020) showed Exclusive breastfeeding was the only postnatal factor that was associated with stunting. Infants who were given exclusive breast milk had a 3.98 times lower risk of stunting compared to babies who did not get exclusive breast milk [15]. Early detection of postpartum depression, intervention, prevention or treatment of maternal depressive disorders, and effective measures will not only reduce the burden of postpartum depression on mothers but will also aid newborn growth [16].

Systematic reviews of 14 studies in low and middle-income countries show that the education of mothers and their partners is the most significant factor in influencing maternal health service use in addition to wealth quintile, media exposure, and rural/urban housing [17]. There are five factors that contribute to stunting, namely: household and family factors, inadequate complementary feeding, inadequate breastfeeding practices, infectious disease factors, and social and community factors. Household and family factors which include: malnutrition during preconception, pregnancy, and breastfeeding, short mothers, infections, teenage pregnancy, mental health, intrauterine growth retard (IUGR) and preterm birth, close labor distance, hypertension, stimulation and activity Inadequate children, poor care practices, Inadequate sanitation and water supply, food insecurity, inadequate household food allocation, and low caregiver education. Inadequate complementary food factors include; poor quality micronutrients in complementary foods, low food diversity and food ingredients containing anti-nutrition, low energy content in complementary foods, rarely, inadequate food during and after illness, consistency of liquid food, insufficient amount of food, food unresponsiveness, contamination of food and water, poor hygiene practices, and unsafe storage and preparation [18].

In Indonesia, the SUN Movement is called the National Movement for the Acceleration of Nutrition Improvement in the Framework of the First 1000 Days of Life, shortened to the First 1000 Days of Life Movement. To formulate the First 1000 Days of Life Movement in Indonesia, a series of activities have been carried out involving key stakeholders consisting of Ministries and Institutions, the business world, international development partners, social and community organizations, and supported by professional organizations, universities, and the media. The First 1000 Days of Life Movement consists of specific nutrition interventions and sensitive nutrition interventions. Specific intervention is an action or activity which in its planning is specifically aimed at the group of the First 1000 Days of Life. These activities are generally carried out by the health sector, such as immunization, supplementary feeding for pregnant women and toddlers, monitoring the growth of toddlers at integrated-service-post, supplementing pregnant women with iron-folate tablets, promoting exclusive breastfeeding, complementary feeding for breast milk, and so on. The specific intervention is short-term, the results can be recorded in a relatively short time. While sensitive interventions are various development activities outside the health sector. The target is the general public, not specifically for the first 1000 days of life. However, if planned specifically and integrated with specific activities, the impact is sensitive to the safety of the growth and development process of the first 1000 days of life [19].

Consistent evidence of the determinant of stunting in Indonesia shows that non-exclusive breastfeeding for the first 6 months, low socioeconomic status of the household, preterm birth, short birth length, low maternal height, and education are determinants of stunting in Indonesia. Breastfeeding children up to the age of two was targeted for measures to avoid stunting in children under the age of two following natural disasters [20]. Households with latrines that are not repaired and untreated drinking water are also at higher risk. Community factors, poor access to health care, and living in rural areas, have been repeatedly linked to stunting [21]. In carrying out infant and child feeding to the extent possible to avoid bottle feeding. If forced to use a milk bottle, a good knowledge of cleanliness and presentation is needed [22]. Counseling is a crucial component of an effective infant and young child feeding. Counseling takes place in person, with the counselor meeting with pregnant women, mothers of toddlers, and caregivers. The benefit of providing infant and young child feeding therapy is that mothers would be aware of their children's nutritional status [23]. Role of midwives and Indonesian midwives Association 
in Reducing Risk Factors for Stunting in Indonesia is important in implementing postnatal care.

The limitation of this study is that the target sample is all midwives in Indonesia, but the sample is not evenly represented in several provinces in Indonesia.

\section{Conclusions}

Implement postnatal care as a duty of midwives has a significant relationship to the prevalence of stunting children under two with a value of $p<0.05$. Role of Midwives in reducing risk factors for stunting in Indonesia is important in implementing postnatal care. The suggestion of this research is that the results of this study can become a policy brief regarding the role and involvement of midwives and the Indonesian Midwives Association in an effort to prevent stunting in Indonesia.

\section{Acknowledgments}

We would like to express our gratitude to the Head of the Human Resources Development and Empowerment Agency for Health of the Republic of Indonesia, to the Director of Palu Health Polytechnic, to all research respondents, and all pregnant women who have prepared the next generation of the Indonesian nation.

\section{References}

1. Penanganan Stunting Terpadu Tahun. Direktur Anggaran Bidang Pembangunan Manusia dan Kebudayaan Kementerian Keuangan. Jakarta: Penanganan Stunting Terpadu Tahun; 2018.

2. Kementerian Kesehatan. Riset Kesehatan Dasar. Jakarta: Kemenkes Rl; 2013. Available from: http://depkes.go.id/ downloads/riskesdas2013/HasilRiskesdas 2013.pdf. [Last accessed on $10 \mathrm{Apr} 2021]$.

3. Kementerian Kesehatan RI. Hasil Utama Riskesdas 2018. Jakarta; Kementerian Kesehatan Rl; 2018. Available from: http:// www.depkes.go.id/resources/download/info-terkini/materi rakorpop 2018/Hasil Riskesdas 2018.pdf. [Last accessed on 12 Mar 2021].

4. Angood C, Khara T, Dolan C, Berkley JA, Group WT. Research priorities on the relationship between wasting and stunting. PLoS One. 2016;11(5):e0153221. https://doi.org/10.1371/ journal.pone. 0153221 PMid:27159235

5. Sumiaty S, Pont AV, Sundari S. Relationship of mother factors, breastfeeding and stunting pattern in central sulawesi. Int J Sci
Basic Appl Res. 2017;35(3):413-20.

6. Agedew E, Chane T. Prevalence of stunting among children aged 6-23 months in Kemba Woreda, Southern Ethiopia: A community based cross-sectional study. Adv Public Health. 2015;2015:164670. https://doi.org/10.4172/2155-9600.1000381

7. Aguayo VM, Badgaiyan N, Paintal K. Determinants of child stunting in the Royal Kingdom of Bhutan: An in-depth analysis of nationally representative data. Matern Child Nutr. 2015;11(3):333-45. https://doi.org/10.1111/mcn.12168 PMid:25536283

8. Nasrul N. Pengendalian faktor risiko stunting anak baduta di Sulawesi Tengah. Promot J Kesehat Masy. 2018;8(2):131-46. https://doi.org/10.31934/promotif.v8i2.495

9. Susiloretni KA, Hadi H, Blakstad MM, Smith ER, Shankar AH Does exclusive breastfeeding relate to the longer duration of breastfeeding? A prospective cohort study. Midwifery. 2019;69:163-71. https://doi.org/10.1016/j.midw.2018.11.008 PMid:30522038

10. IBI Jabar. Definition of Midwife. 2018. Available from: http:// www.ibijabar.org/bidan/definisi/. [Last accessed on 10 Apr 2021].

11. Malouf $R$, Redshaw M. Specialist antenatal clinics for women at high risk of preterm birth : A systematic review of qualitative and quantitative. BMC Pregnancy Childbirth. 2017;17(51):1-17. https://doi.org/10.1186/s12884-017-1232-9

PMid:28148230

12. World Health Organization. WHORecommendationsonAntenatal Care for a Positive Pregnancy Experience. Geneva, Switzerland: World Health Organization; 2016. Available from: http://www. apps.who.int/iris/bitstream/10665/250796/1/9789241549912eng.pdf?ua=1. [Last accessed on 10 Mar 2021].

13. Svefors P, Sysoev O, Ekstrom EC, Persson LA, Arifeen SE, Naved RT, et al. Relative importance of prenatal and postnatal determinants of stunting: Data mining approaches to the MINIMat cohort, Bangladesh. BMJ Open. 2019;9(8):e025154. https://doi.org/10.1136/bmjopen-2018-025154

14. Schmidt MK, Muslimatun S, West CE, Schultink W, Gross R, Hautvast JG. Nutritional status and linear growth of Indonesian infants in west java are determined more by prenatal environment than by postnatal factors. J Nutr. 2002;132(8):2202-7. https:// doi.org/10.1093/jn/132.8.2202 PMid:12163663

15. Krisnana I, Widiani NM, Sulistiawati S. Prenatal and postnata factors related to the incidence of stunting in the coastal area Surabaya, Indonesia. Sri Lanka J Child Health. 2020 Sep 5;49(3):223-229.

16. Sharmin KN, Sarwar N, Mumu SJ, Taleb DA, Flora MS Postnatal depression and infant growth in an urban area of Bangladesh. Midwifery. 2019;74:57-67. https://doi.org/10.1016/j. midw.2019.03.014 PMid:30927633

17. Banke-Thomas $\mathrm{O}$, Banke-Thomas $\mathrm{A}$, Ameh CA. Utilisation of maternal health services by adolescent mothers in Kenya: Analysis of the demographic health survey 2008-2009. Int $J$ Adolesc Med Health. 2018;30(2):42. https://doi.org/10.1515/ ijamh-2016-0042 PMid:27732558

18. Stewart CP, lannotti L, Dewey KG, Michaelsen KF, Onyango AW. Contextualising complementary feeding in a broader framework for stunting prevention. Matern Child Nutr. 2013;9(S2):27-45. https://doi.org/10.1111/mcn.12088 PMid:24074316

19. Bappenas RI. Pedoman Perencanaan Program Gerakan Nasional Percepatan Perbaikan Gizi Dalam Rangka Seribu Hari Pertama Kehidupan (Gerakan 1000 HPK). Jakarta: Bappenas 
RI; 2013.

20. Hafid F, Taqwin T, Linda L, Nasrul N, Ramadhan K, Bohari B. Specific interventions to prevent stunting in children under 2 years after the natural disaster. Open Access Maced $\mathrm{J}$ Med Sci. 2021;9:64-9. https://doi.org/10.3889/oamjms.2021.5677

21. Beal T, Tumilowicz A, Sutrisna A, Izwardy D, Neufeld LM. A review of child stunting determinants in Indonesia Matern Child Nutr. 2018;14(4):1-10. https://doi.org/10.1111/ mcn.12617

\section{PMid:29770565}

22. Nasrul N, Hafid F, Ramadhan K, Suza DE, Efendi F. Factors associated with bottle feeding in children aged 0-23 months in Indonesia. Child Youth Serv Rev. 2020;116:105251. https://doi. org/10.1016/j.childyouth.2020.105251

23. Faisal E, Hafid F, Kusumawati DE, Nasrul N, Jurana J. The implementation of infant and young children feeding counseling. Open Access Maced J Med Sci. 2021;9:224-8. https://doi. org/10.3889/oamjms.2021.5882 